\title{
Social Entrepreneurship in Slovenia: An Opportunity for Sustainable Development?
}

\author{
LJILJANA RIHTER* \\ Faculty of Social Work \\ University of Ljubljana \\ Ljubljana, Slovenia
}

\author{
Izvorni znanstveni rad \\ UDK: 364.014(497.4) \\ doi: $10.3935 /$ rsp.v25i3.1492 \\ Primljeno: kolovoz 2017.
}

\section{ROMANA ZIDAR}

Social economy in Slovenia was been regulated and supported on the state level for two decades after independence. It could be explained as a consequence of breakdown of a socialist tradition, when the main notion was that the state could solve any problem. In the time of transition from the socialistoriented to the market-oriented economy, social economy was not taken into consideration. Nevertheless, there were some particular initiatives, especially in the field of social protection of the vulnerable groups (employment of persons with physical disabilities or mental health problems) and in the field of ecology (farming) which were regulated by particular laws. The initiators of social entrepreneurship were faced with various obstacles yet on the other hand there was a space to develop various ideas and to respond to the needs in the society/community. These initiatives will be presented with the focus on identifying possible topics which need to be taken into consideration in the process of implementation of the law on social entrepreneurship in order to put more emphasis on sustainable development.

Key words: social economy, social entrepreneurship, sustainable development.

* Ljiljana Rihter, Univerza v Ljubljani, Fakulteta za socialno delo / University of Ljubljana, Faculty of Social Work, Topniška ulica 31, 1000 Ljubljana, Slovenija / Slovenia, liljana.rihter@fsd.uni-lj.si 


\section{INTRODUCTION}

A concept of social economy and/or social entrepreneurship has a long tradition in various parts of the world and some basic values of social economy had been developed at the end of the $19^{\text {th }}$ century, such as democratic associationism, mutualism, cooperativism (Chaves, Monzón Campos, 2007). Nevertheless, more emphasis on the importance of social entrepreneurship has been noticed in the last decades in various European countries. When trying to explain the basic concepts of social economy and social entrepreneurship, one could notice that sometimes these terms are used interchangeably (Yunus, 2009) while other authors (Leadbeater, 1997, Chavez, Monzón Campos, 2007:20) offer definitions of particular terms which are not entirely mutually exclusive.

Yunus (2009) argues that social entrepreneurship presents a phase in an evolution of social economy which appeared when we realized that in addition to a number of human needs and besides the seemingly most important one (maximizing the profit), the need to solve problems within the society and environmental problems is equally important.

Social enterprises present, in addition to cooperatives, mutual societies, non-profit associations, and foundations, one of the organisational forms in the area of social economy.

Chavez and Monzón Campos (2007:20) define social economy through the legal organizational forms where the activities are implemented:

- private, formally-organised enterprises, "...with autonomy of decision and freedom of membership, created to meet their members' needs through the market by producing goods and providing services, insurance and finance, where decision-making and any distribution of profits or surpluses among the members are not directly linked to the capital or fees contributed by each member, each of whom has one vote";

- private, formally-organised organisations "...with autonomy of decision and freedom of membership that produce non-market services for households and whose surpluses, if any, cannot be appropriated by the economic agents that create, control or finance them."

The social economy charter (CEDAG, 2007) sets out some basic characteristics of social economy that is founded on the principles of solidarity and individual involvement in a process of active citizenship and that generates high-quality jobs, a better quality of life, and offers a framework suited to new forms of enterprise and work. It plays an important role in local development and social cohesion, it is socially responsible, it is a factor of democracy and it contributes to the stability and pluralism of economic markets. Social economy corresponds to the European Union's priorities and strategic objectives: social cohesion, full employment and the fight against poverty, participatory democracy, better governance and sustainable development. Principles could be considered as benchmark criteria for different forms of civil society organisations and businesses which consider themselves as part of social economy. Principles are also inclusive and can be applied to classical for-profit businesses which wish to operate in a socially responsible manner and even to governmental agencies during procurement procedures. the above defined characteristics served as a basis for the delimitation of the social economy by the Charter of Principles of the Social Economy promoted by the European Standing Conference on Co-operatives, 
Mutual Societies, Associations and Foundations (CEP-CMAF) (Chavez, Monzón Campos, 2007:17).

Social entrepreneurship is, as already written, one of the possible formal forms of social economy. Leadbeater (1997:2-4) defines social entrepreneurship by differing it from classical entrepreneurship, especially when it comes to the main objectives of the two. Social entrepreneurship is based on the growth of social capital instead of the growth of profit (as in the classical entrepreneurship), it is a market response to social, environmental, local problems and its basic goal is ensuring social welfare. Business measures are used to achieve social goals. The main results of this endeavour could be: new innovative welfare services and new ways of delivering existing services. He also identifies the organizational forms within which social entrepreneurs deploy entrepreneurial skills for social ends: parts of the traditional public sector, some large private sector corporations and the voluntary sector.

Borzaga and Defourny (2001: 29-32) draw from the EMES (2001) research network data when defining main social and economic characteristics of social enterprise. The economic characteristics are: continuous activity of producing and/ or selling goods or services, high level of autonomy (social enterprises' main source of revenues are voluntarily contributions and are self-governed - owners have the right to freely choose the activity and to cease the activity), business-risk (financial capability of social enterprises depend on members' activities to ensure adequate financial resources), defined minimal percentage of employed workers. The social characteristics are: one of the basics aims is to create social well-being (to serve the community or a defined group of people), citizens' initiative to found a social enter- prise due to some common needs and aims, management is not based on the ownership share but on the democratic principle of one member - one vote, participatory principle (all stakeholders participate including users) and limited profit sharing.

For the purposes of this article the CEP-CMAF (Chaves, Monzón Campos, 2007:17) definition of social economy and Borzaga and Defourny's (2001:29) definition and conceptualization of social enterprise have been used as a basis for understanding of both terms. Even if some authors use these terms interchangeably, in the majority of definitions we can identify the idea that the term social economy is a broader one and social entrepreneurship is one of the possible legal forms of social economy. This corresponds to new Social Entrepreneurship Act (Zakon o dopolnitvah zakona o socialnem podjetništvu, Uradni list RS, št 13/2018) that is addressing frequent conceptual ambiguities. According to the mentioned act, social economy includes various legal entities, such as social enterprises, associations, institutes, cooperatives, foundations and other entities, where main business objective is not solely gaining profit, but also creating tangible and non-tangible benefits for their members, clients and communities at large. Although social enterprise should comply with a number of rules in order to gain and maintain its status, conceptual confusion is still present. The main reason behind frequent practice of interchangeable use of terms could be attributed to the fact that social economy is a concept, based on a set of business principles that are trying to create a distinguished image, or rather a "brand" of responsible, participatory, inclusive, democratic, not-exploitative, communityoriented businesses that care about people and the planet, but within frameworks of capitalistic production and consumption. 
For this reason we understand and use the term social entrepreneurship as being a part of a wider concept of social economy, thus intentionally referring to social economy when trying to refer to a wider conceptual framework of social entrepreneurship.

The paper presents some of the main characteristics of social economy and social entrepreneurship in Slovenia, focusing primarily on a recent development in this field and on the legislative regulation. Since Slovenia was lagging behind many of other European states, passing the law on social entrepreneurship only in 2011, the potential of social entrepreneurship will be discussed firstly, followed by a brief analysis of the law, primarily focusing on how legislative solutions are corresponding with the definition of social economy presented above (Chavez, Monzón Campos, 2007: 17), and especially on how the Slovenian law complies with the definition of social entrepreneurship characteristics as defined by Borzaga and Defourny (2001: 29-32). At the end, some crucial topics will be discussed. Because sustainable development is one of frequently overlooked European Union's priorities and strategic objectives, we will discuss the possibilities of further development of legislation and its implementation in the field of social entrepreneurship in order to follow this objective on the basis of results of a small scale quantitative research. It has been conducted on a population of registered social enterprises in Slovenia on May 15, 2018. The main goal of the paper is to delineate basic challenges that social enterprises are facing in Slovenia while trying to achieve the goals of social economy with a special focus on sustainable development. In the concluding part we will present some recommendations for strengthening the re- lationship between social entrepreneurship and sustainable development.

\section{SOCIAL ECONOMY AND SOCIAL ENTREPRENEURSHIP IN SLOVENIA}

Even though the act regulating social entrepreneurship in Slovenia was adopted only in the year 2011 (Zakon o socialnem podjetništvu, Uradni list RS, št. 20/2011), Slovenia has a long history of social economy. In the first part of the chapter we will present the history and potential for the development of social economy. In the second one we will focus on current legal regulation and critically examine it.

\section{The potential that was overlooked?}

The first major obstacle when researching social economy in Slovenia during the first twenty years of the state's existence is the absence of a clear definition of which institutions or organizations could be understood as part of social economy sector that is often also named as the third sector. Borzaga and Defourny (2001:7) mention that most of the states have its own definition of the third (social) economy sector, usually including various social and economic initiatives which are neither part of the public nor the profit sector. Researchers of the third sector in Slovenia classified social enterprises as an integral part of the third sector, traditionally differing from business/for-profit sector due to its pro-social and pro-environmental values guiding their programs and activities (social objectives, public good, etc.) (Kolarič et al., 2002).

Considering Borzagas' and Defournys' (2001:29-32) definition of the main social and economic characteristics of social enterprise it can be assumed that when Slovenia was still part of ex-Yugoslavia ${ }^{1}$ led

\footnotetext{
${ }^{1}$ Slovenia was the first of the former Yugoslav republics to organize multi-party elections in April 1990.
} 
by socialist government, all enterprises had at least some of the characteristics of social enterprise (for instance: democratic management - self-governing; enhancing social well-being - enterprises were founded to serve the whole community or the whole society), even if they were not termed so.

Nevertheless, in times of transition to a market-oriented society in the early $1990 \mathrm{~s}$ these goals were to some extent neglected as the heritage of the socialist's era, carrying many negative attributes that needed to be collectively rejected and abandoned as soon as possible. For this reason mainly 'third' sector organizations maintained some characteristics of the social enterprise. Their primary objective is to pursue positive social change in benefit of general-public-good or in benefit of organizations' members and not to follow objectives that are generating-profit for owners. The organizations are categorized in five groups: societies and associations, private institutes, foundations, cooperatives, faithbased organizations and other forms. Two main researches in the third sector field in Slovenia (Kolarič et al., 2002, Kolarič et al., 2006) show a growth of the sector, yet a closer look at the data shows a somewhat different picture - the growth was more in quantitative than in qualitative terms. It is also worth mentioning the additional data on areas of activities performed by the organisations composing the third sector. The majority of them perform sports and recreational activities, culture and artistry, yet on the other hand there are a few organizations dealing with research, law, advocacy, international cooperation, ecology etc.

When reviewing employment as one of the most important indicators of social economy sector development, Slovenia is somehow lagging behind as a generator of waged employments when compared to other European countries. The data from a research of the third sector for the year 2004 in Slovenia (Kolarič et al., 2006) reveal that the share of employed persons in the non-profit non-governmental organizations represents only $0.74 \%$ of the active population. More than $80 \%$ of these organizations perform their activities without employed personnel, yet the volunteers' working hours equal about 7,000 workers. The income of these organizations represents only $1.91 \%$ of GDP and the main sources of income are public sources (slightly above one third), the sources from selling the goods and services (slightly below one third), about one fifth of all incomes are represented by donations and the remaining part (about 13\%) are the incomes from other non-defined sources.

Meanwhile the data for the European Union show a different picture. Chavez and Monzón Campos (2007:43) conclude that social economy in Europe is very important in both human and economic terms. In this sector over 11 million people were employed in the year 2002 in the states of EU-15, which is equivalent to about $6 \%$ of the working population of the EU, and in Slovenia the respective percentage was only $0.5 \%$.

Another important area when analysing capacities of enhancing social economy in Slovenia were the active employment policy measures that were based on the priorities set by the European Commission and Slovenian government and that coincided the period of 2007 - 2013 European Union program financing. The program of active employment policy measures for the period 2007-2013 (MDDSZ, 2007) and similarly Active employment policy implementation guidelines for the period 2016-2020 (MDDSZ, 2015) list a number of goals, among which two are closely linked with the social economy. The first one is promoting employment and self-employment and 
the second one is encouraging social inclusion. Main measures in the area of promoting employment and self-employment were supporting business and employment programs with counselling, stimulating employment of older unemployed persons, non-market employment programs etc. Within the goal of intensifying social inclusion, the measures of enhancing employment and self-employment of difficult-to-employ persons (and among them especially the persons receiving social assistances) were planned: counselling, subventions for employers, innovations, public works, home assistance, personal assistance, employment programs for persons with disabilities and enhancement of employment in the third sector (non-governmental organizations) for the development of new social programs. It can be concluded that the program of active employment policy measures have provided the possibility for the development of social economy even more in the field of social programs and public services and less in the market-oriented organizations.

There were also several other strategic documents mentioning social economy in Slovenia (Operational programme of human resources development 2007 - 2013 (Government Office for Local Self-Government and Regional Policy, 2007), Where to after crisis? Contribution to sustainable vision for Slovenian future (Gregorčič et al., 2009), programme document of Zares political party (2008:21) etc.). None of them had predicted any concrete policies for enforcement on the legislative level.

The Ministry of Labour, Family and Social Affairs had co-financed nine pilot projects of social entrepreneurship in the year 2009 through the European Social Fund (MGRT, 2015). Yet there is no evaluation available which could show the results (good practices or the obstacles that organizations implementing the projects' activities were facing) of these pilot projects.

Both the numeric data and the analysis of existing documents till the year 2011 have shown a moderate potential to develop a sector of social economy. The main question that derived from those initiatives was how to balance the social (employment of persons from vulnerable groups, social aims) and economic (business ideas) characteristics of social enterprise. If we considered social enterprise mainly as a solution to reduce the number of difficult-to-employ people, than the business ideas would remain behind and there would be a danger of inefficient economic operation. And inversely, if the business idea was above all other factors there would be a problem of neglecting the needs, interests and competences of the employees. Therefore we need to focus on another important element which needs to be considered when re-thinking the status of social enterprises in Slovenia - the element of the law regulation.

\section{Law regulation in the field of social economy - critical examination}

In the Slovenian legislation, the act regulating social entrepreneurship was adopted in the year 2011 (Zakon o socialnem podjetništvu, Uradni list RS, št. 20/2011) with minor amendments adopted in 2014 and major amendments in 2018 (Zakon o spremembah in dopolnitvah zakona o socialnem podjetništvu, Uradni list RS, št. 13/2018). There are a few additional laws and regulations indirectly linked to social economy that are regulating legal organizational forms, which according to Chavez and Monzón Campos (2007) could be a part of social economy sector (e. g. act on societies, act on institutions, act on foundations, act on cooperatives), or are regula- 
ting certain activities with characteristics of social enterprises (e.g. act on employment rehabilitation and employment of persons with disabilities). These acts enable some activities that could be categorized as social economy.

Social Entrepreneurship Act (Zakon o socialnem podjetništvu, Uradni list RS, št. 20/2011) (hereinafter SEA) was adopted partly due to pressures from the European Union to adopt legal frameworks that would allow the development of formal overarching system of social economy (see, for example, the European Parliament Resolution of 19 February 2009 on Social Economy. (2008/2250(INI)). Additionally, there was a strong initiative in the Slovene Parliament to adopt such law. One of the main goals of policy makers was to define rights and obligations of social enterprises, what conditions should be met to comply with the definition of social enterprise, which business activities are considered as social entrepreneurship and special employment criteria that give certain priorities to the most vulnerable groups on the labour market.

Previous SEA distinguishes between two different types of social enterprises. The first type is defined according to the fields of activities of social interests, which have to be implemented and the second according to the vulnerable groups that should be employed in such entities (Zakon o socialnem podjetništvu, Uradni list RS, št. 20/2011). With amendments to the SEA (Zakon o spremembah in dopolnitvah zakona o socialnem podjetništvu, Uradni list RS, št. 13/2018), this distinction was replaced by a looser definition of what conditions businesses should fulfil in order to obtain a status of social enterprise. This could potentially lead to the transformation of classical businesses into social enterprises only in order to access benefits and incen- tives. With the enforcement of an amended act, social enterprises should create social benefit through corresponding business activities or by employing persons from vulnerable groups.

Main objectives of the SEA are:

- strengthening solidarity in society, cohesion and voluntarism,

- developing innovative solutions for social, economic and environmental problems,

- providing an additional range of socially beneficial services and products,

- developing employment opportunities and job creation, targeting individuals from the most vulnerable groups on the labour market.

A closer look at the listed objectives reveals that more emphasis is given to social characteristics of social enterprise, but with one major flaw. There was no preassessment of needs, wants and competencies among vulnerable groups and no market analysis was prepared, and this would not only fuel the development of law, but would also reflect real-time situation. Even more, after the law was adopted no comprehensive empirical research was foreseen or implemented that would allow the development of sound strategy followed by a quality action plan. For this reason it could be assumed that the law was based on the notion that social economy is merely the social corrective factor, and was not considered as a possible small-scale alternative to for-profit economy, too often failing to cater to the needs of certain niche segments of consumers, but also creating segregated working environments and not pushing mainstream labour market to include the most vulnerable groups into their working environments. This contradicts the objective of foreseeing social integration.

Basic principles of social entrepreneurship as defined by SEA greatly correspond 
to the principles mentioned in The Social Economy Charter (CEDAG, 2007). The main difference can be observed within the principle of the primacy of the individual and the social objective over capital objective (profit sharing). SEA defines nonprofitability as the main purpose of social enterprise (which is in line with the above mentioned principle), yet in one of the following articles the possibility of profitsharing is mentioned, limiting $20 \%$ of income to be shared on yearly basis to either members, board or employees. Such loose definition of who could benefit from profit is paving the way for privileges and possible manipulation.

Members are, according to the second article of SEA, individuals who hold management rights in the social enterprise, such as the founders of a social enterprise or the owners of a social enterprise, others with equity interests, as well as individuals with the member status in case of a membership organization. In all these examples they have a right to participate in the decision-making process related to all aspects of the enterprise. Yet the employees without the status of a member have rather limited rights to participate in decision-making processes and other important aspects of social enterprise business-wise decisions. Their participation is limited to the decisions about working conditions and quality of products and/or services. On the other hand, members have the right to decide upon all aspects according to the principle: one member, one vote (Zakon o socialnem podjetništvu, Uradni list RS, št. 20/2011, Zakon o spremembah in dopolnitvah zakona o socialnem podjetništvu, Uradni list RS, št. 13/2018).

Any non-profit legal entity (especially associations, private non-profit institutions, foundations, companies with limited liability, disability companies and employment centres) can apply for the status of social enterprise when fulfilling some basic conditions: it must carry out economic and non-economic activities; have definition of a restriction on the distribution of surplus revenue over expenses or assets between members or stakeholders of a social enterprise in its internal acts; be independent and organizationally autonomous in relation to profit-making companies; be a legal entity governed by public law or local communities; provide an inclusive form of governance based on co-decision and democratic decision-making, and meet other conditions stipulated by the SEA and it has to operate according to the principles of social entrepreneurship. (Zakon o spremembah in dopolnitvah zakona o socialnem podjetništvu, Uradni list RS, št. 13/2018).

Some of the conditions and/or regulations could be perceived as risks considering lessons learned from disability companies' practices. According to the information available on a portal of Statistical Office of the Republic of Slovenia (2010), the disability companies in the year 2008 were employing in total 13,704 people with average wage $63.1 \%$ below the Slovenian average. Primary business activity in about $65.5 \%$ of disability companies was manufacturing, where the work is physically exhaustive and does not fulfil the condition of quality work place for workers, including those from vulnerable groups. The situation in employment centres where social inclusion programs are implemented is even worse, especially for the individuals whose productivity is challenged. People engaged in these programmes have earned on average 72 euros per month in 2008 (Vidmar et al., 2009:69). On the basis of this data one cannot assume that social enterprises will automatically provide quality working environments with fair wages. In Slo- 
venia some empirical data also show how employment agencies for providing workers were violating labour rights of workers (Leskošek et al., 2009). Additional risk is that similar agencies specializing in workers who are at the same time experiencing different vulnerabilities would follow similar practices, especially considering the fact that people facing different forms of discrimination and social exclusion are not very vocal, often because they are lacking access to user-friendly information about their rights and possibilities and are afraid to claim them (Rihter, Kobal, 2007).

Another flaw that can be identified is the tendency to categorize people on the basis of their vulnerabilities in two general categories. The first one is not putting any constraints on the durability of "vulnerability", that is how long an individual is considered vulnerable. The second one puts time constraints to understanding of vulnerability - an individual is considered to be vulnerable only during the first year of employment in a social enterprise. This limitation was intended to encourage social enterprises to actively search for more sustainable solutions without government assistance, but since social enterprises were regulated in term of business activity and in terms of hiring of workers (the need to employ groups excluded from labour market) as well as labour rights monitoring, such limitations could create situations of dismissal from employment after a year, with negative experience of being condemned to insecure, flexible working arrangement, regardless of their motivations, capacities or productivity. Such manoeuvres could enable employers to fulfil their legal obligations defined in SEA (Zakon o socialnem podjetništvu, Uradni list RS, št. 20/2011), according to which they need to prove on yearly basis that they employ a certain number/percentage of people from the vul- nerable groups. This obligation has been changed with amendments to the law (Zakon o spremembah in dopolnitvah zakona o socialnem podjetništvu, Uradni list RS, št. $13 / 2018$ ) and is not in force any more. It was burdening not only for employees, but it also created a high turnover of staff and negatively influenced business operations and revenues.

Even if the basic ideas behind SEA (Zakon o socialnem podjetništvu, Uradni list RS, št. 20/2011, Zakon o spremembah in dopolnitvah zakona o socialnem podjetništvu, Uradni list RS, št. 13/2018) correspond to the European Union guidelines (European Parliament resolution of 19 February 2009 on Social Economy (2008/2250(INI)), a deeper look reveals different factors negatively influencing employment opportunities and experiences of workers challenged by different vulnerabilities, pushing them further away from labour market integration. As observed in an applicative situational analysis of social economy in Slovenia (Babič, Dabič Perica, 2018), vulnerability persists even though employment opportunity arises within social enterprise. Currently a new strategy for the development of social economy is being prepared by the responsible ministry. This strategy will include social enterprises and should further build on the previous and also the first strategy which was valid from 2013 until 2016. One of the strategic goals of the previous strategy was oriented towards inclusion of the vulnerable groups in the labour market through employments in social enterprises. This included subventions to the employers, piloting and further development of WISE (work integration in social enterprise) model in Slovenia, trainings of management staff to enhance their capacities in management as well as their skills of working with vulnerable populations, and finally targeting of active em- 
ployment policies towards social enterprises. Unfortunately, a comprehensive analysis of results achieved in the framework of the previous strategy is missing, since coordination of social entrepreneurships was moved from the Ministry of Labour, Family, Social Affairs and Equal Opportunities to the Ministry of Economic Development and Technology. Authors of the analysis of the social economy system (Babič, Dabič Perica, 2018), indicating its ambition to expand narrow understanding and frequent misunderstanding of the concept of social entrepreneurship, announcing the preparation of new strategy, have failed to include the analysis of the first strategy, even though it is clear that certain strategic goals where enforced in 2018 - e.g. co-financing of WISE workshops.

A critical analysis of the previous strategy would also be valuable with regard to the sustainability of the initiatives, projects and business that were initiated in that period and to address shortcomings of the first strategy.

\section{SOCIAL ENTREPRENEURSHIP AND SUSTAINABLE DEVELOPMENT: CAN WE EXPECT MUTUAL EFFECTS?}

It is surprising that even a broad research report on the social economy in the European Union (Chaves, Monzón Campos, 2007) does not explicitly discuss the role of social economy as the promoter of sustainable development. It is emphasized that social economy has an important role in social cohesion, local and region development, innovation, competitiveness, democratization of the entrepreneurial role, employment, correcting imbalances in the labour market. Sustainable development is only mentioned among other roles, such as contribution to the fair distribution of inco- me and wealth, creation and provision of welfare services, development of civic initiatives and citizen involvement, deepening democracy and increasing the efficiency of public policies (Chaves, Monzón Campos, 2007:109). Yet in the Charter of Principles of the Social Economy promoted by the European Standing Conference on Co-operatives, Mutual Societies, Associations and Foundations (CEDAG, 2007) it is explicitly stated that most of the surpluses of social economy are used in pursuit of sustainable development objectives. The same is true for the European Parliament resolution of 19 February 2009 on Social Economy (2008/2250(INI).

In the Slovene SEA (Zakon o socialnem podjetništvu, Uradni list RS, št. 20/2011, Zakon o spremembah in dopolnitvah zakona o socialnem podjetništvu, Uradni list RS, št. 13/2018) there is no explicit link or emphasis on the sustainable development, but there are more indirect statements when mentioning the goals of social entrepreneurship as for instance to develop innovative solutions for social, economic, environmental problems. The first SEA (Zakon o socialnem podjetništvu, Uradni list RS, št. 20/2011) was limiting activities in which social enterprises could engage, but a few of them could be attributed to sustainable development, such as eco-food production, animal protection, environmental protection and nature conservation, social tourism, social and fair trade, culture and heritage conservation. Yet changes to SEA in 2018 (Zakon o spremembah in dopolnitvah zakona o socialnem podjetništvu, Uradni list RS, št. 13/2018) do not explicitly include any special activity any more.

Though Elsen (2010) states that the field of social economy presents the potential for sustainable development, we can argue that the Slovene SEA (Zakon o socialnem podjetništvu, Uradni list RS, št. 20/2011) is to 
some extent limited when considering the potential of sustainable development. Review of the SEA namely shows that it does not have many characteristics of so-called 'solidarity economy' which is controlled through solidarity, generates social capital through cooperation and the joint management of resources, focuses on common good as the principle of action and gives importance to a globalized solidarity acknowledging that we are part of a social and ecological whole (Elsen, 2010:136). On the contrary, SEA emphasizes the "third sector' discourse which is focused more on the entities providing activities of social economy than on cooperation or community-driven economy.

According to Elsen (2010), the concept of community-driven economy is close to the sustainable development issues. Community-driven economy is based on "....inextricable entity of use, creation and distribution of the material bases of life (....) shaping of socio-cultural life nexuses through forms of vertical collectivisation based on associationism and voluntary action." (Elsen, 2010:135). Existing forms of the community-driven economy are based on fundamental, human, social and ecological needs. Therefore community-driven economy is defined in the context of concepts of socio-economic self-organization of civil society, of organized forms of solidarity to secure people's livelihood, integrating and emancipating disadvantaged people and preserving the basis of life in the community (Elsen, 2010:140). Similarly Bežovan (2005:388-389) points out that social economy, especially in European countries, is based on self-organization of groups at the community level.

In the Slovene SEA (Zakon o socialnem podjetništvu Uradni list RS, št. 20/2011) the meaning of community-based strategic approach which is theoretically guided by the social development model with main characteristics of increasing communication, collaboration and ownership among community members (Hawkins, Weis, 1985) and/or meaning of needs is not defined. It is only stated that the local communities can (but are not obliged to) plan, finance and implement a policy for social entrepreneurship development. This statement on the one hand leaves the opportunity to develop community-driven economy and possibilities of sustainable development, yet on the other hand there is no guarantee that the social enterprises will reflect the real needs of the respective community and that there will be any participation of various stakeholders, which is according to current thinking (Beausyte-Petrauskiene, 2007) the condition that leads to capacity building and sustainability.

The analysis of social economy sector in Slovenia (Babič, Dabič Perica, 2018) that has been published recently provides some general assessments of the realization of social economy principles and goals. It reveals that the majority of social enterprises include voluntary work, assert equality of membership, all stakeholders can participate in business management, they provide for transparency of performance and they assess that their activities are for public good. Nevertheless the analysis does not give an exact answer on sustainable development issues. It has also revealed that the majority of social enterprises perform activities that are not explicitly bound to sustainable development.

Due to the absence of the data on activities that are performed in social enterprises in Slovenia that could be part of sustainable development, we performed a quantitative research among the population of social enterprises registered in Slovenia on 15th May 2018. An invitation with the request to participate in the survey was sent to the 
total of 202 social enterprises from the National register of social enterprises, led by the Directorate for regional development, Sector for social entrepreneurship, cooperatives and economic democracy, which is part of the Ministry of Economic Development and Technology. The invitation with the link to the respective web-survey was sent in two rounds; the first of 17th of May 2018 was sent with the request to complete the survey until 31st of May 2018. After the first round, 39 social enterprises completed the survey, and therefore the deadline for completion was extended for additional 14 days. In total 44 social enterprises completed the survey, 11 of them only partly. This huge discrepancy between the registered number and the number of completed questionnaires can have an impact on the validity of results. Nevertheless, a low response rate is not an unusual issue since other researchers have had similar or even lower response rates as well (Babič, Dabič Perica, 2018). In addition to the basic questions about the legal organizational form, the core activity, the number of employees (including vulnerable groups) and volunteers, we especially wanted to know the following: What was the incentive for registration as social enterprise? What is the contribution to the sustainable development of society? How do they measure social effects? How do they evaluate their products / services in the context of corporate social responsibility? What is the assessment of state measures to promote social entrepreneurship?

According to the legal organizational form, 39\% of responding social enterprises are institutes, $32 \%$ are societies and/or their associations, $18 \%$ cooperatives, $16 \%$ limited liability companies, $2 \%$ are declared as simply social enterprise. $11 \%$ of respondents did not have any employees, $58 \%$ have between 1 and 4 employees,
$17 \%$ between five and nine, $6 \%$ between ten and fourteen and $8 \%$ fifteen and more. $61 \%$ of respondents also employ persons from vulnerable groups (mainly persons who were long-term unemployed, first job seekers, disabled persons, older workers). More than two thirds of responding social enterprises also include volunteers. This corresponds to the results of the research conducted by Babič and Dabič Perica (2018) where respondents pointed out that a great deal of work in the organisations is done voluntarily. Even though volunteer work is frequent in start-up organisations, some precautions and safeguarding mechanisms should be adopted, especially when vulnerable groups are employed in order to assure no voluntary overtime work is done with consent given out of fear of losing a job.

Basic activities of our respondents vary. Out of 37 answers, only education and training, catering, other businesses and business consulting were selected more than once. We can estimate that about $20 \%$ of social enterprises perform activities which are more closely linked to the ideas of sustainable development. Nevertheless, others can also have goals connected with these issues and this is more exactly presented in the following results. Their estimations of claims about the main reasons for establishing the social enterprise show that almost all $(94 \%)$ agree or strongly agree with the claim 'We registered as a social enterprise because our business activity is sustainable.' and $92 \%$ agree or strongly agree with the claim 'We registered a social company because we want to act in accordance with the principles of social entrepreneurship.' Additionally, 64\% agree or strongly agree with the claim 'We registered a social company because we want to employ vulnerable groups in the labour market.' It is in accordance with our presumption that 
principles of social economy are the main promoter of the activities and among them sustainable development is obviously an important one. Less agreement (53\% agree or strongly agree) can be noticed while assessing the claim 'We registered a social company because it enables us to engage in economic activity'. Even less agreement can be noticed while assessing claims of the role of the local community. Only $38 \%$ of respondents agree or strongly agree with the claim 'We registered a social company because of the incentive of the community in which our organization / company operates.' The main goals they intend to achieve as regards sustainable development are linked to: commitment to the healthier life-style of population (65\% of respondents), promoting sustainable, inclusive and sustainable economic growth, full and productive employment and decent work for all $(62 \%)$, reduction of poverty rates $(53 \%)$, and nearly a half of them contribute to ensuring sustainable production and consumption patterns, reducing discarded food, promoting recycling, and so forth $(47 \%)$, while slightly less $(44 \%)$ contribute to the achievement of gender equality.

One of our objectives was to look into the methods and/or ways of measuring intended social goals of social enterprises. $77 \%$ of respondents agree with the statement 'The effects of our business and operations are measured when it comes to project work, in accordance with the requirements of co-financiers.' A half of them measure and monitor the economic, social and environmental effects with their own methodology. About $40 \%$ of them do not measure the effects regularly due to the shortage of knowledge or persons who could perform it. A similar percentage measures the effects with the purpose of creating a marketing strategy or with the purpose of communicating with the public and designing educational and convincing messages. Regardless of the above mentioned shortages, while assessing their goals the respondents are strongly convinced that their products are socially responsible; they strengthen solidarity in community; their products can solve environmental problems and are innovative.

As regards their assessment of the role of the state in providing measures to enhance the development of social economy, we can conclude that they are quite critical and skeptical. Only $22 \%$ agree or strongly agree with the claim 'There are sufficient resources and opportunities to access various services that enable the creation of a favorable business environment, such as incubators, support for start-up businesses and co-financing of new jobs'. 19\% agree or strongly agree with the claim 'The availability of more favorable loans, guarantees and subsidies from budgetary sources is good and contributes to the positive performance of our company'. There is even less agreement $(13 \%)$ with the claim 'Financial measures designed to promote the development of social entrepreneurship in the form of various public tenders allow access to sufficient financial resources for projects that contribute to the development of our social enterprise.' It shows that financial support or financial measures do not respond to the needs of social entrepreneurs. When adding results from the analysis of social economy field in Slovenia (Babič, Dabič Perica, 2018) which shows that municipalities do not get involved much more as supportive environments and that they co-financed only public works, it all leads to clear conclusion. Environment (neither on state nor on local level) is currently not seen as a supportive one by the social entrepreneurs. Yet we have found out that they are slightly more satisfied with active employment policy measures 
and public tenders even if they do not provide the necessary personnel stability yet. Similar findings can be noticed in a recent research on social economy. Respondents were critical about the fact that most of the employments were co-financed in the framework of public works, which are part of active employment strategy (Babič, Dabič Perica, 2018). The main objective of public works is to assure labor inclusion, social activation and the development of labor skills of long-term unemployed, meaning that they cannot fully participate in the working process or be effective as they are frequently expected to be. Such a situation not only affects wellbeing and selfconfidence of workers who were excluded from labor market for a year or more and need more support and encouragement to reintegrate, but it also slows down the development of social enterprises, especially those which are heavily relying on statesponsored workforce. Due to the limitation of the duration of public works (max. 2 years), frequent fluctuation of workforce means constant training of new people, shifting the main focus from business operations towards human resource management.

\section{CONCLUSION}

It is of great importance that almost twenty years after the breakdown of the socialist system and independence, the debate on the meaning of social economy in Slovenia has intensified and became visible. In the socialist times all enterprises had at least some of the characteristics of social enterprise (democratic management - selfgoverning; enhancing social well-being enterprises were founded to serve the whole community or the whole society), yet in the transition period economic values have prevailed over the social.
We can assume that the topic has gained growing interest due to at least two reasons. One is the recommendation of the European Parliament resolution of 19 February 2009 on Social Economy (2008/2250(INI)) and the other is the economic crisis that Slovenia was facing until recently, and which contributed to the worsening of employment opportunities for the members of vulnerable groups to find and keep a decent job.

The legislation related to social entrepreneurship (Zakon o socialnem podjetništvu Uradni list RS, št. 20/2011) that has been adopted seven years ago and amended recently (Zakon o spremembah in dopolnitvah zakona o socialnem podjetništvu, Uradni list RS, št. 13/2018) provides clear rules and procedures on how to establish a social enterprise and defines the social enterprises as entities similarly to Chavez and Monzón Campos (2007). Certain flaws noticeable in the first SEA could be summarized as: poor consistency when non-profit legal entities are being defined, definition of stakeholders and their roles in social enterprises is too vague, system of profit sharing is arbitrary, differentiation between various vulnerable groups (different rights for various groups) is unnecessary and even harmful, since it supports flexible employments and involvement of employment agencies. These flaws were creating risks that could potentially lead towards poor practical implementations. Similar deficiencies were also identified in an analysis of social economy field in Slovenia (Babič, Dabič Perica, 2018). Some legislative flaws were already corrected through legislation amendments (Zakon o spremembah in dopolnitvah zakona o socialnem podjetništvu, Uradni list RS, št. 13/2018). For instance, the system of profit sharing has been changed (no profit sharing is allowed); differentiation between rights 
of various vulnerable groups is abolished. Therefore we can expect some improvements related to these issues in the future, but certain risks are still present, for example business activities in which social enterprises can engage were dismissed, which could potentially lead to the transformation of classical businesses into social enterprises only to access benefits and incentives. Ideally changes in the formal structure would also initiate a change in mind-set of decision makers in organisations and influence the sustainability of business processes and results, but practice will show if this will be the case.

The deficiencies are even more obvious when considering the potential of social economy for benefit of sustainable development. In the present SEA there is no clear link to the sustainable development with current provisions which are not offering firm basis for the development of community-based or solidarity-based economy (Elsen, 2010) that is able to focus on real needs.

Therefore one could conclude that the potential to develop social entrepreneurship led by the ideas of sustainable development is rather moderate in Slovenia. Yet at the same time one cannot expect that the notion of social economy as stated in the present SEA (Zakon o spremembah in dopolnitvah zakona o socialnem podjetništvu, Uradni list RS, št. 13/2018) will bring substantial benefits to sustainable development.

Nevertheless, the results of our smallscale research show that main incentives for the registration as social enterprise are connected to performing activities that are sustainable and are based on the principles of social entrepreneurship. Fewer incentives are connected to cooperation or community-driven economy. The main goals that about a half of social enterprises intend to achieve as regards sustainable development are linked to commitment to the healthier life-style of population, promoting sustainable, inclusive and sustainable economic growth, full and productive employment and decent work for all, reduction of poverty rates, ensuring sustainable production and consumption patterns, reducing discarded food, promoting recycling, and so forth. On the basis of our results we can argue that the majority of respondents do not have clear methods and/or clear purposes of monitoring and measuring achievements of their stated goals. They measure them mainly when co-financers require it, having their own methodology (and we do not know its validity and possibility to compare the results of various social enterprises). Additionally, they also emphasize that they do not measure the effects regularly due to the shortage of knowledge or persons who could perform it. Regardless of the above mentioned shortages, while assessing their goals, the respondents are strongly convinced that their products are socially responsible; they strengthen solidarity in community; their products can solve environmental problems and are innovative. As regards their assessment of the role of the state in providing measures to enhance the development of social economy they are quite critical and skeptical. Financial support or financial measures do not respond to the needs of social entrepreneurs. According to their assessments, they are slightly more satisfied with active employment policy measures and public tenders even if they do not provide the necessary personnel stability.

The analysis of social economy field in Slovenia and guidelines for the future strategy in this field (Babič, Dabič Perica, 2018) gives an even more optimistic view. Possible market opportunities that were identified have a clear link to sustainable 
development. According to Babič and Dabič Perica (2018), more emphasis should be given to rural development, green economy and green working places; self-care, agriculture, recycling and reuse. Empowerment of local communities is emphasized as one of the main strategic goals for the forthcoming strategy.

On the basis of the analysis of legislation regulating social entrepreneurship we can conclude that it gives only moderate potential to sustainable development issues. Yet the results of our small-scale research show a slightly different picture. Social enterprises assess sustainable development as an important issue and goal. Additionally, the guidelines for forthcoming strategy are much more in line with sustainable development issues compared to the existing legislation. In order to have more informative data while evaluating sustainable development potential of social enterprises, it is important for the responsible ministry to take into consideration this issue while preparing a methodology for monitoring social impact of social enterprises. As regards necessary legislation changes, more emphasis should be given to the role of local communities supporting social entrepreneurs' initiatives, since it was identified as one of the main deficiencies in promoting community driven economy.

\section{REFERENCES}

Babič. K., \& Dabič Perica, S. (2018). Aplikativna analiza stanja na področju socialne ekonomije $v$ Republiki Sloveniji. Ljubljana: Ministrstvo za gospodarski razvoj in tehnologijo. Dostupno na http://www.mgrt.gov.si/fileadmin/ user_upload/Analiza_stanja_na_podrocju_socialne_ekonomije_v_Sloveniji.pdf

Baušytė-Petrauskienè, A., \& Lepaite, D. (2007). Competence structure of sustainable development project stakeholders in the changing project management paradigm. Social Sciences, 58(4), 37-49.
Bežovan, G. (2005). Socijalna politika i neprofitni sektor. U V. Puljiz, G. Bežovan, Z. Šućur, S. Zrinščak (ur.), Socijalna politika (str. 387425). Zagreb: Pravni fakultet.

Borzaga, C., \& Defourny, J. (2001). L'impresa sociale in prospettiva europea: diffusione, evoluzione, caratteristiche e interpretazioni teoriche. London: Routledge.

Chaves, R., \& Monzón Campos, J. L. (2007). The social economy in the European Union. Brussels: CIRIEC.

Elsen, S. (2010). Social work and community-based social economies. Reflections on the task of socio-political development. In D. Sandu (Ed.), European Societies in Transition: Social Development and Social Work (pp. 131-158). Berlin: Lit Verlag.

EMES International Research Network. (2001). European Research Network. Available at https://emes.net/

European Council of Associations of General Interest. (2007). The Social Economy Charter. Brussels: CEDAG.

European Parliament. (2009). European Parliament resolution of 19 February 2009 on Social Economy (2008/2250(INI)). Available at http://www.europarl.europa.eu/sides/ getDoc. do? pubRef $=-/ / \mathrm{EP} / / \mathrm{NONSGML}+\mathrm{TA}+\mathrm{P} 6-\mathrm{TA}-$ 2009-0062+0+DOC+PDF+V0//EN

Government Office for Local Self-Government and Regional Policy. (2007). Operativni program razvoja človeških virov 2007-2013. Dostupno na http://www.eu-skladi.si/kohezija-do-2013/ predpisi/operativni-programi/2007-2013/operativni-program-razvoja-cloveskih-virov

Gregorčič, M., Hanžek, M., Kajfež-Bogataj, L., Kreft, L., Murn, A., Plut, D., Stanovnik, T., Školč, J., \& Trontelj, J. (2009). Kam po krizi? Prispevek $k$ oblikovanju trajnostne vizije prihodnosti Slovenije. Dostupno na http://www. nekdanji-pv.gov.si/2008-2012/fileadmin/ kpv.gov.si/pageuploads/datoteke_dinamika/2009_12/drugo/24dec2009_kam_po_krizi_SLO.p.pdf

Hawkins, J. D., \& Weis, J. G. (1985). The social development model: an integrated approach to delinquency prevention. Journal of Primary Prevention, 6(2), 73-97. https://doi. org/10.1007/BF01325432 
Kolarič, Z., Črnak-Meglič, A., Rihter, L., Boškić, R., \& Rakar, T. (2006). Velikost, obseg in vloga zasebnega neprofitnega sektorja $v$ Sloveniji (raziskovalni projekt v okviru CRP - celovita analiza pravnega in ekonomskega okvirja za delo nevladnih organizacij): Zaključno poročilo. Ljubljana: Fakulteta za družbene vede, Center za proučevanje družbene blaginje.

Kolarič. Z., Črnak-Meglič, A., \& Vojnovič, M. (2002). Zasebne neprofitno-volonterske organizacije v mednarodni perspektivi. Ljubljana: Založba FDV.

Leadbeater, C. (1997). The rise of the social enterpreneur. London: DEMOS.

Leskošek, V., Zaviršek, D., Kresal, B., Rihter, L., Smolej, S., Boškić, R., Sobočan, A., \& Jeseničnik, N. (2009). Vzroki in obseg pojava zaposlenih revnih: končno poročilo. Ljubljana: Fakulteta za socialno delo.

Ministrstvo za delo, družino, socialne zadeve i enake možnosti. (2007). Program ukrepov aktivne politike zaposlovanja 2007-2013. Dostupno na http://www.mddsz.gov.si/fileadmin/ mddsz.gov.si/pageuploads/dokumenti__pdf/ apz_2007_2013.pdf

Ministrstvo za delo, družino, socialne zadeve i enake možnosti. (2015). Smernice za izvajanje ukrepov aktivne politike zaposlovanja za obdobje 2016-2020. Dostupno na http://www. mddsz.gov.si/fileadmin/mddsz.gov.si/pageuploads/dokumenti_pdf/zaposlovanje/Smernice_APZ_2016_2020_final.pdf
Ministrstvo za gospodarski razvoj in tehnologijo. (2015). Socialno podjetnišstvo. Dostupno na http://www.mgrt.gov.si/si/delovna_podrocja/ socialno_podjetnistvo/

Rihter, L., \& Kobal, B. (2007). "I look like a mess ... Am I needed in the profit-oriented society?": The labour market and employment situation of some vulnerable categories of unemployed and inactive people in Slovenia. Revija za socijalnu politiku, 14(3-4), 373-390. https://doi. org/10.3935/rsp.v14i3.687

Statistični urad Republike Slovenije. (2010). Novica. Ljubljana: SURS.

Yunus, M. (2009). Novemu kapitalizmu nasproti. Socialno podjetništvo za svet brez revščine. Tržič: Učila International.

Vidmar, J., Sužnik, J., Bedenik, L., Pintarič, A., Podbreznik, N., Zadravec, S., Gošnjak, E., \& Kolar, Š. (2009). Evalvacija izvajanja programov socialne vključenosti v letu 2008. Ljubljana: Univerzitetni rehabilitacijski inštitut.

Zakon o dopolnitvah zakona o socialnem podjetništvu. Uradni list $R S$, št. 13/2018.

Zakon o socialnem podjetništvu. Uradni list $R S$, št. 20/2011.

Zares politična stranka. (2008). Zares pripravljeni na izzive! Za nov razvojni dogovor, za novo razvojno politiko. Predlog programskega dokumenta Zares - nova politika. Dostupno na http://www.zares.si/category/program/ 


\section{Sažetak}

\section{SOCIJALNO PODUZETNIŠTVO U SLOVENIJI: PRILIKA ZA ODRZ̆IVI RAZVOJ?}

\section{Ljiljana Rihter}

Univerza $v$ Ljubljani,

Fakulteta za socialno delo

Ljubljana, Slovenija

\section{Romana Zidar}

Socijalna ekonomija u Sloveniji nije bila regulirana i podržana na državnoj razini dva desetljeća nakon samostalnosti. Ovo se može objasniti kao posljedica sloma socijalističke tradicije, kada je glavna zamisao bila da država može riješiti bilo koji problem. U vrijeme prijelaza iz socijalističko orijentiranu na tržišno orijentiranu ekonomiju, socijalna ekonomija nije uzeta u obzir. Ipak, bilo je nekih posebnih inicijativa, posebice u području socijalne zaštite ranjivih skupina (zapošljavanje osoba s tjelesnim invaliditetom ili problemima $s$ mentalnim zdravljem) i na području ekologije (poljoprivrede) koje su regulirane posebnim zakonima. Inicijatori socijalnog poduzetništva suočeni su s različitim preprekama, no s druge strane postojao je prostor za razvoj različitih ideja i odgovora na potrebe društva I zajednice. Ove inicijative bit će predstavljene s naglaskom na utvrđivanje mogućih tema koje treba uzeti u obzir u procesu primjene zakona o socijalnom poduzetništvu kako bi se stavio veći naglasak na održivi razvoj.

Ključne riječi: socijalna ekonomija, socijalno poduzetništvo, održivi razvoj. 